\title{
Structure degradation of the plasma spray thermal barrier coating on the blade during operation
}

\author{
J. O. Zavaleta T. ${ }^{\dagger}$, V. Yu. Hristosova, O. S. Bondareva \\ †zavatisna@hotmail.es \\ ${ }^{1}$ Samara National Research University, 34 Moskovskoye shosse, Samara, 443086, Russia
}

\begin{abstract}
Thermal barrier coatings are widely used to protect blades of gas turbine engines from exposure to high-temperature flow. In this work, we considered coatings applied by the plasma spray method and consisting of the NiCoCrAlY heat-resistant sublayer and the $\mathrm{ZrO}_{2}+8 \% \mathrm{Y}_{2} \mathrm{O}_{3}$ upper ceramic layer. The aim of the work was to study the thermal barrier coating microstructure in the initial state and after long-term operation for 8000 hours to predict the possibility of further exploitation. It is shown that the coating is not destroyed, there are no chipping and peeling. However, the upper ceramic layer is sintered under the influence of high-temperature gas flow, its porosity decreases, and therefore the heat-shielding properties are reduced. At the boundary of the heat-resistant layer and the nickel base, a diffusion zone is formed. It is characterized by significant chemical heterogeneity and release of topologically closed packed phases (TCP-phases). These phases are lamellar carbides of tungsten and chromium. They can be stress concentrators and reduce fatigue resistance. In addition, the $\gamma$-solid solution is depleted of refractory alloying elements, which leads to a softening of the alloy. The obtained data show significant structural degradation of the thermal barrier coating and the subsurface area of the blade. Thus, the blade with a resource operation is only recommended in surface facilities.
\end{abstract}

Keywords: thermal barrier coatings, the plasma spray method, the NiCoCrAlY, the $\mathrm{ZrO}_{2}+8 \% \mathrm{Y}_{2} \mathrm{O}_{3}$, diffusion zone and topologically closed packed phases.

\section{Деградация структуры термобарьерного покрытия, нанесенного методом плазменного напыления, на лопатке во время эксплуатации}

\author{
Савалета Т. Х. О. ${ }^{\dagger}$ Христосова В. Ю., Бондарева О.С. \\ ${ }^{1}$ Самарский национальный исследовательский университет, Московское ш., 34, Самара, 443086, Россия
}

\begin{abstract}
Термобарьерные покрытия широко используются для защиты лопаток газотурбинных двигателей от воздействия высокотемпературного потока. В данной работе мы рассмотрели покрытия, нанесенные методом плазменного напыления и состоящие из термостойкого подслоя $\mathrm{NiCoCrAlY}$ и верхнего керамического слоя $\mathrm{ZrO}_{2}+8 \% \mathrm{Y}_{2} \mathrm{O}_{3}$. Целью работы было изучение микроструктуры термобарьерного покрытия в исходном состоянии и после длительной эксплуатации в течение 8000 часов с целью прогнозирования возможности дальнейшей эксплуатации. Показано, что покрытие не разрушается, отсутствуют сколы и отслоения. Однако верхний керамический слой спекается под воздействием высокотемпературного газового потока, его пористость уменьшается, и поэтому теплозащитные свойства снижаются. На границе термостойкого слоя и никелевой основы образуется диффузионная зона. Она характеризуется значительной химической неоднородностью и выделением топологически плотноупакованных фаз (ТПУ-фаз). Эти фазы представляют собой пластинчатые карбиды вольфрама и хрома. Они могут быть концентраторами напряжений и снижать усталостную прочность. Кроме того, $\gamma$-твердый раствор обеднен тугоплавкими легирующими элементами, что приводит к разупрочнению сплава. Полученные данные показывают значительную деградацию структуры термобарьерного покрытия и подповерхностной области лопатки. Таким образом, попатка с истекшим сроком эксплуатации рекомендуется только на наземных сооружениях.
\end{abstract}

Ключевые слова: термобарьерные покрытия, метод плазменного напыления, NiCoCrAlY, $\mathrm{ZrO}_{2}+8 \% \mathrm{Y}_{2} \mathrm{O}_{3}$, диффузионная зона и топологически плотноупакованные фазы. 


\section{Introduction}

The industrial processes that involve operations at high temperatures, where these reach ranges above $1000^{\circ} \mathrm{C}$, as is the case of the gas turbines operation [1], where your pieces need to be made of materials resistant to this environment. In this materials group stand Nickel's superalloys, which with the help of their components are able to resist these operations, but at frequently operating temperature cycles, these cause wear and degradation of their properties. One way to mitigate these damages is by using barriers, that covering different applications and uses from the study of their properties, how to reinforce them by adding elements in their structure or modifying nanostructurally to improve them [2-4], and within them we find the thermal barrier coatings [5-7]. There are different deposition forms of this coatings type, one of these methods is the plasma spray coating, with which two protective layers are formed on the substrate, which fulfill different functions [8-11]. As a top layer, a ceramic is used, which is composed of yttrium oxide stabilized tetragonal zirconia polycrystals (Y-TZP) $[12,13]$ perceives the thermal and erosive effects of the gas flow and reduces the temperature of the blade. Under the ceramic layer is NiCoCrAlY heat-resistant layer, which protects the base metal from oxidation and contributes to the adhesion strength of the ceramic layer to the substrate $[14,15]$.

When these coatings and the substrate are subjected to destructive effects of the high temperature current, it leads to structural changes in both the layer of the coatings, with the loss of barrier properties [16,17]; and the formation of the diffusion zone where harmful closed packed phases (TCP) abound that destroy the mechanical properties of the superalloy $[18,19]$.

Therefore, the objective of the work was to study these effects in the microstructure of the plasma thermal spray barrier coating, for which the initial state and after the longterm operation were analyzed to predict the possibility of further exploitation.

\section{Methods and materials}

To analyze the initial structures and after the exploitation, the nickel superalloy ZhS6F was chosen as the blade substrate and the protective barriers were the NiCoCrAlY bond coat and tetragonal zirconia polycrystals stabilized with $8 \%$ yttrium oxide (Y-TZP) as the top layer. These materials have a wide use in the finished parts industry of a gas turbine and were deposited by the plasma spray method.

The blades with coatings were subjected to real conditions of thermal cycles of operation in a long term approximately 8000 hours. Operating experience shows that damage to the coating on the blades surface is not the same at the leading edge (Fig. 1a), the suction side (Fig. 1b), the trailing edge (Fig. 1c) and the pressure side (Fig. 1d). Scheme cross section of the gas turbine engines blade is shown in Fig. 1.

The microstructure of the sample was studied after electrolytic etching on TESCAN Vega SB scanning electron microscope with INCA Energy dispersive microanalyzer.

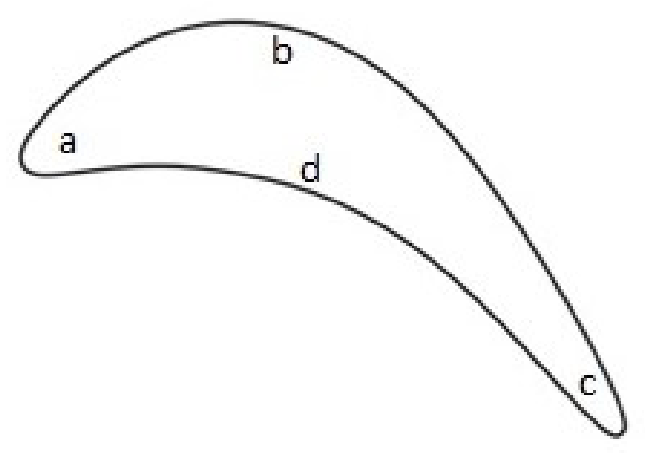

Fig. 1. Scheme cross section of blade: leading edge (a), suction side (b), trailing edge (c), pressure side (d) [20].

\section{Results and discussions}

Visual inspection has shown that the destruction of the coating in the form of chips, delaminations and stripping is absent. The thermal barrier coating microstructure in the characteristic areas of the blade in the initial state and after operation is shown in Fig. 2, 3.

The study of the ceramic layer microstructure showed that after operation the number of pores and microcracks significantly decreased, and the porous ceramic coating was compacted. This suggests that under the action of hightemperature gas flow, ceramics sintering and thermal barrier properties deterioration occur. Examination of the heatresistant layer structure showed no change. At the same time, a more detailed study of the alloy/coating boundary showed that a diffusion zone appears in the base metal structure under the coating after operation. It is a region with allocation of the secondary lamellar phases.

It should be noted that the diffusion zone structure at the pressure side and suction side of the blade differs from the zone structure at the loading edge (Fig. 4).

Characteristic structural differences of the diffusion zone at the pressure side and the suction side of the blade from the zone at the leading edge are formations of a needleshaped phase under the coating (Fig. 4), that describe the shape and location of the phase plates. Also this diffusion zone is distributed in greater thickness on the substrate in the loading edge zone than other zones of the turbine blade and generate an average thickness of $36.34 \mathrm{~mm}$ (Table 1).

The increase in chemical heterogeneity in the coating and the subsurface after operation is clearly demonstrated by mapping (Fig. 5).

The element composition of secondary phases in the diffusion zone showed that the inclusions are enriched with tungsten, chromium and carbon (Fig. 6 and Table 2).

Table 1. The thickness in diffusion zone measurements at 4 specific zones of the turbine blade made after the exploitation test.

\begin{tabular}{|c|c|}
\hline Areas analyzed in the sample & $\begin{array}{c}\text { The thickness in diffusion zone } \\
(\mu \mathrm{m})\end{array}$ \\
\hline Leading edge & 65.16 \\
\hline Suction side & 9.94 \\
\hline Trailing edge & 21.27 \\
\hline Pressure side & 49.00 \\
\hline Average & 36.34 \\
\hline
\end{tabular}



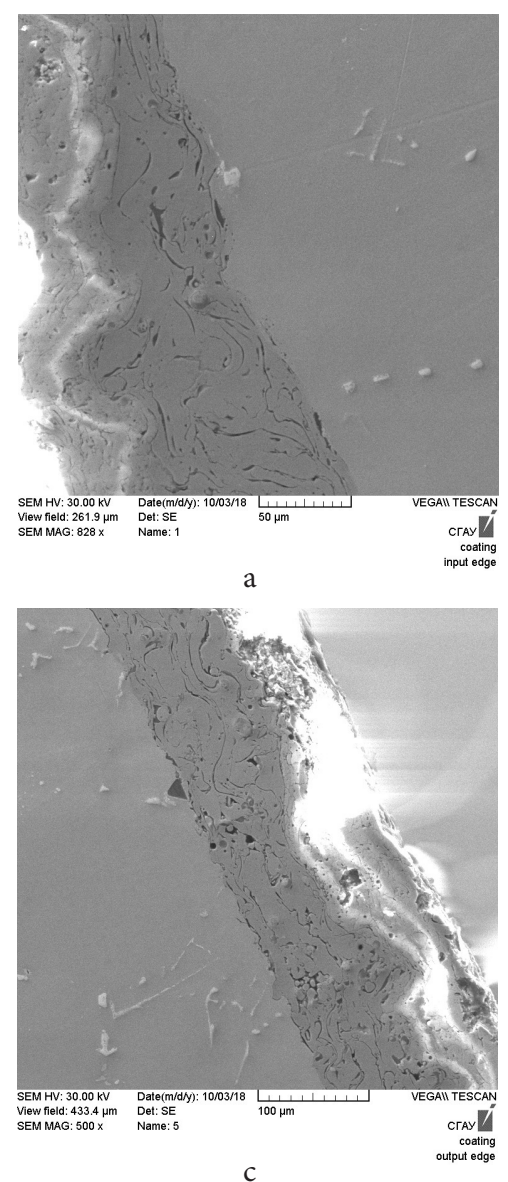
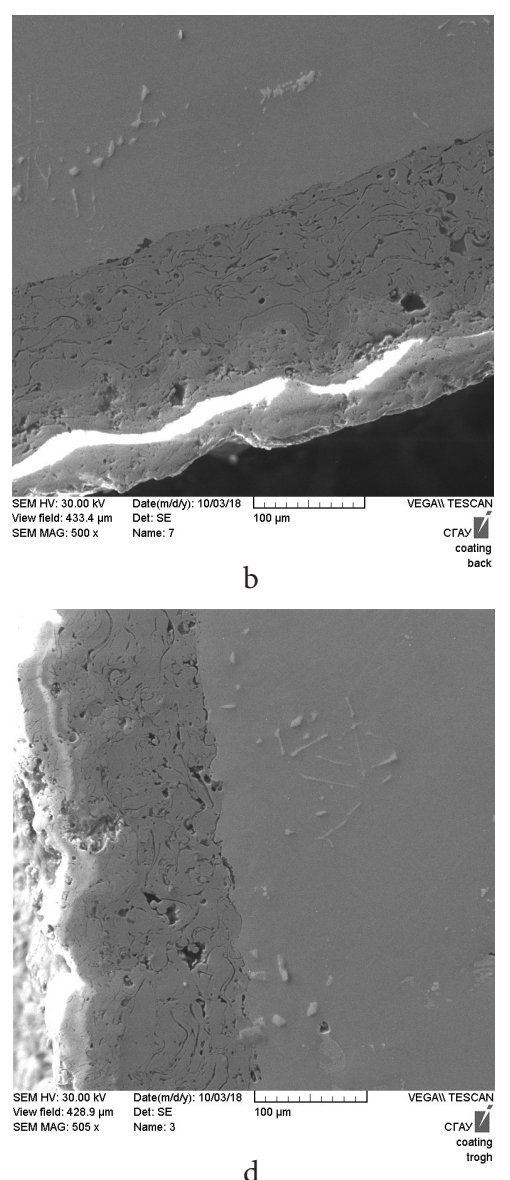

d

Fig. 2. The thermal barrier coating microstructure in the initial state: leading edge (a), suction side (b), trailing edge (c), pressure side (d).
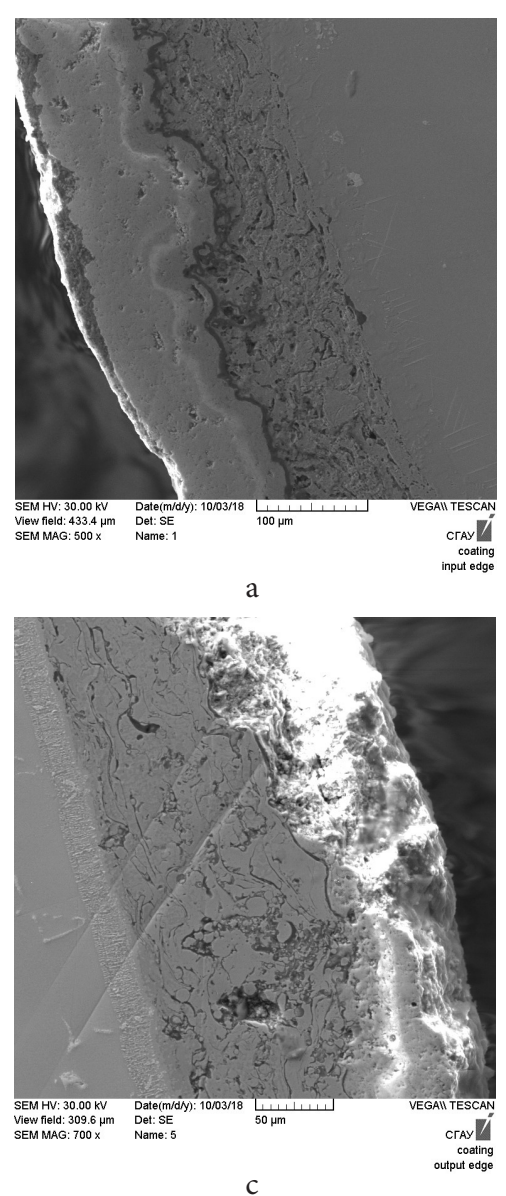

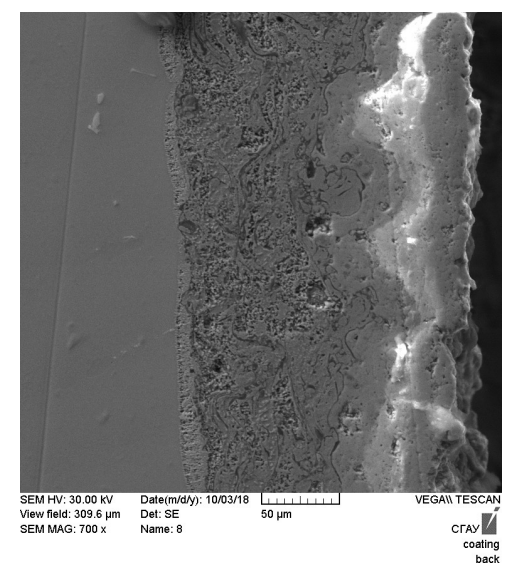

$\mathrm{b}$

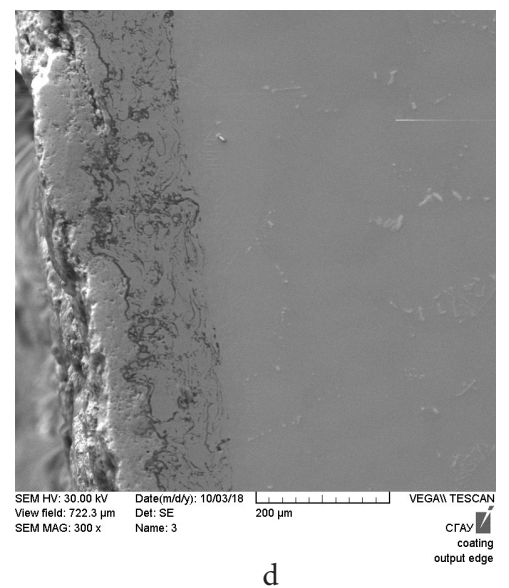

Fig. 3. The thermal barrier coating microstructure after operation: leading edge (a), suction side (b), trailing edge (c), pressure side (d). 

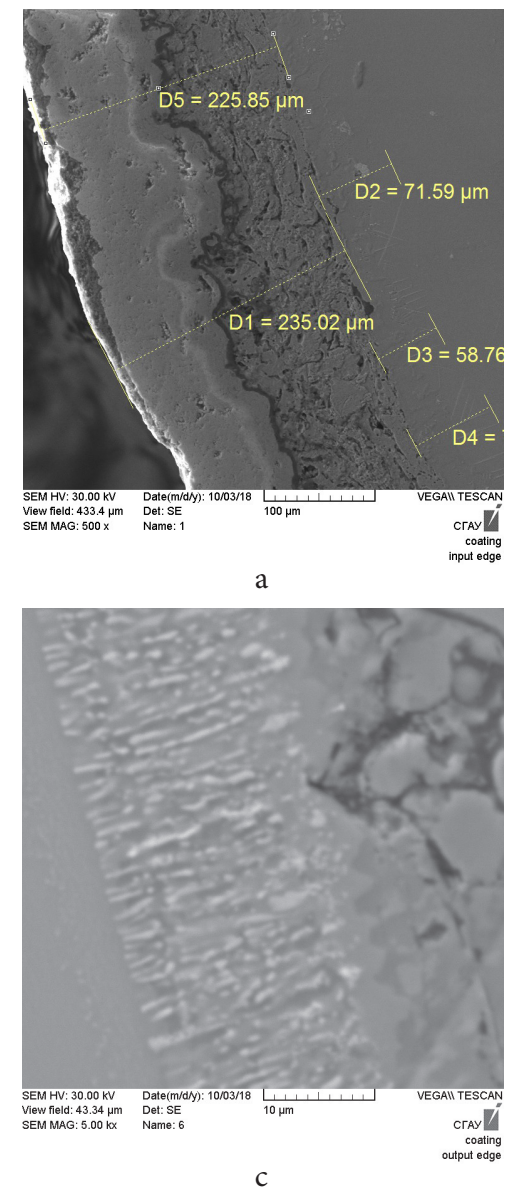

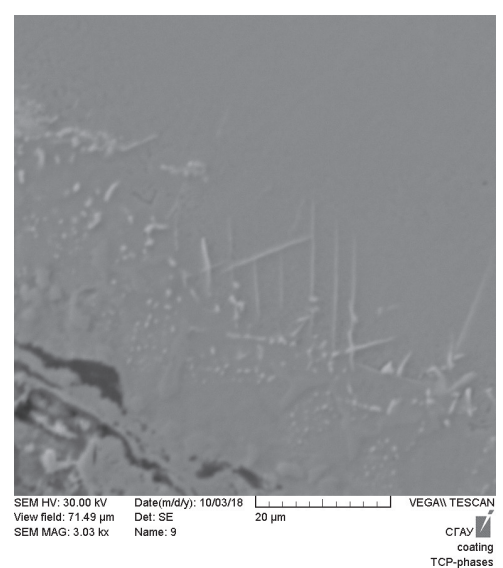

$\mathrm{b}$

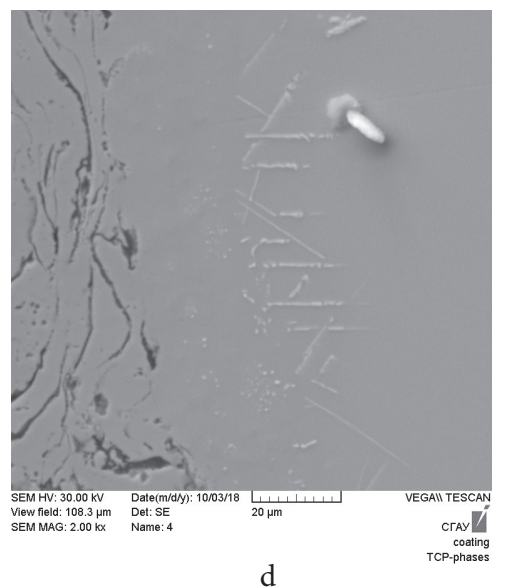

Fig. 4. The diffusion zone in the base metal structure on the blade working surface: leading edge (a), suction side (b), trailing edge (c), pressure side (d).
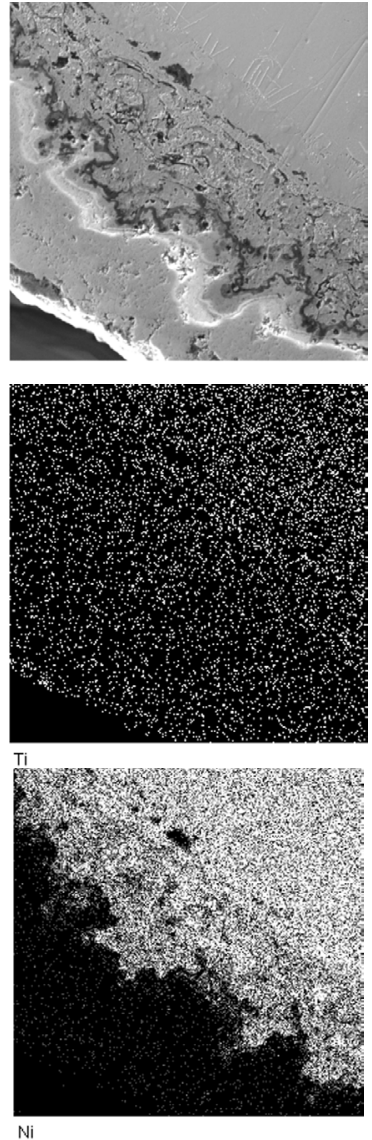

Fig. 5. Coating mapping after operation.
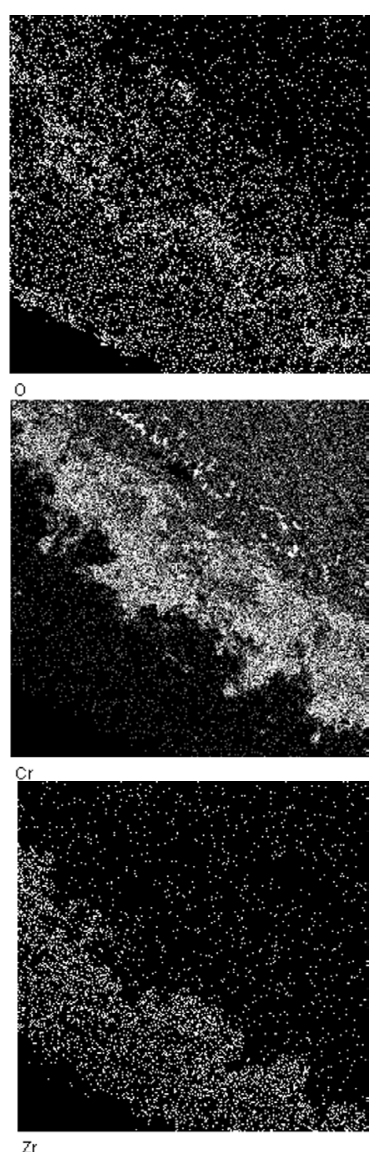
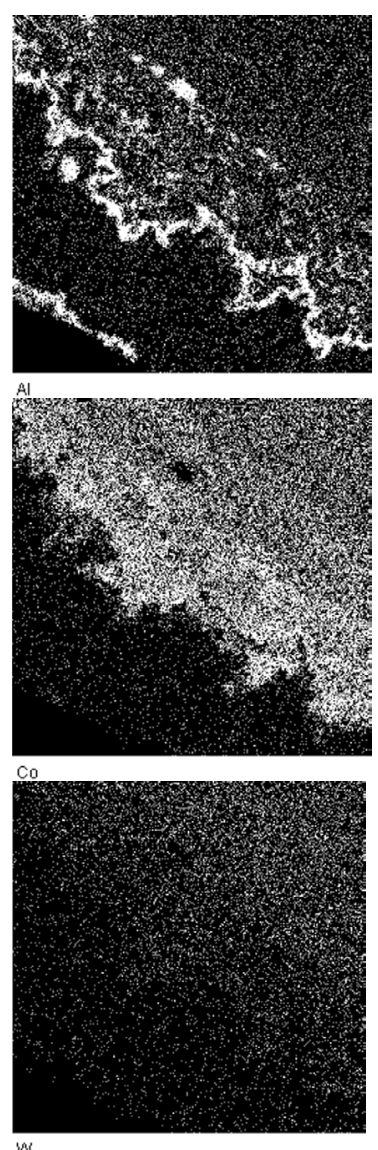
Table 2. The chemical composition in points 1 and 2 of Fig. 6.

\begin{tabular}{|c|c|c|c|c|c|c|c|c|c|c|c|}
\hline \multirow{2}{*}{ Location } & \multicolumn{10}{|c|}{ The mass percentage of elements (\%) } & \multirow{2}{*}{ Total } \\
\hline & $\mathrm{C}$ & $\mathrm{O}$ & $\mathrm{S}$ & $\mathrm{Al}$ & $\mathrm{Ti}$ & $\mathrm{V}$ & $\mathrm{Cr}$ & Co & $\mathrm{Ni}$ & $\mathrm{W}$ & \\
\hline 1 & 7.33 & - & - & 5.04 & 1.03 & 0.90 & 5.89 & 12.5 & 57.02 & 10.3 & 100 \\
\hline 2 & 9.28 & 0.40 & 0.95 & 2.13 & 0.59 & 1.19 & 9.13 & 10.81 & 37.70 & 27.82 & 100 \\
\hline
\end{tabular}

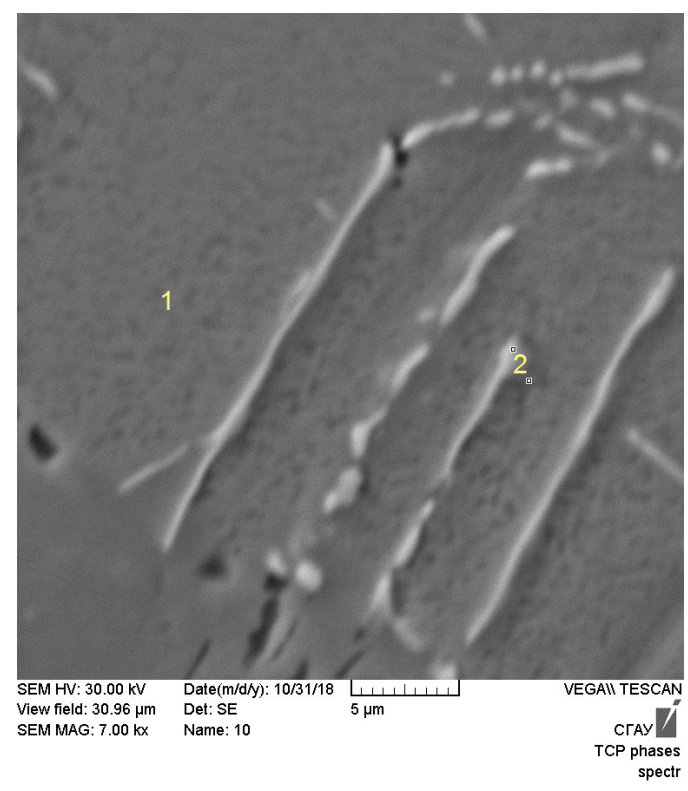

Fig. 6. The topologically closed packed phases.

It is known that $\operatorname{Ti}(\mathrm{C}, \mathrm{N}), \mathrm{Cr}_{2}(\mathrm{C}, \mathrm{N}), \mathrm{Cr}(\mathrm{C}, \mathrm{N})$ carbonitrides are formed in nickel alloys, reducing fatigue resistance. Particles of $\mathrm{M}_{6} \mathrm{C}, \mathrm{Cr}_{23} \mathrm{C}_{6}, \mathrm{TiC}$ carbides and carbonitrides concentrate in the $\gamma / \gamma^{\prime}$ phase matrix. These phases are topologically closed packed phases (TCP phases) [21-23]. With an increase in the oxidation time, coagulation of tungsten-chromium-based carbides occurs. TCP phases have a complex crystal structure. Furthermore, such phase plates are stress concentrators and a source of initiation and propagation of cracks [24]. In addition, the $\gamma$-solid solution is depleted of refractory alloying elements, whichleads to the softening of the alloy [25]. The formation of the above phases in the base metal structure under the coating is a sign of a decrease in the protective coating reliability and heat resistance of the gas turbine engine blades.

\section{Conclusions}

Data analysis has shown that after prolonged operation of the blade plasma spray thermal barrier coating microstructure undergoes significant changes. The upper ceramic layer is sintered under the influence of high-temperature gas flow, its porosity decreases. At the boundary of the heat-resistant layer and the nickel base, a diffusion zone is formed. It is characterized by significant chemical heterogeneity and release of TCP phases. Lamellar tungsten and chromium carbides can be stress concentrators and reduce fatigue resistance.

These data suggest a significant structural degradation of the thermal barrier coating. Blades with resource exploitation are recommended to use only in surface facilities.

\section{References}

1. F.I. Demin, N.D. Pronichev, I.L. Shitarev. Tekhnologiya izgotovleniya osnovnykh detaley gazoturbinnykh dvigateley. Samara, SSAU Publishers (2010) 328 p. (in Russian). [Ф.И. Демин, Н. Д. Проничев, И. Л. Шитарев. Технология изготовления основных деталей газотурбинных двигателей. Самара, Изд-во СГАУ (2010) 328 с.]

2. A.P. Surzhikov, T. S. Frangulyan, S. A. Gungasov, I. P. Vasiliev. Glass and ceramics. 71 (9-10), 373 (2015). Crossref

3. S.V. Konovalov, V.E. Kormyshev, V.E. Gromov, Y. F. Ivanov, E. V. Kapralov, A. P. Semin. Journal of Surface Investigation. 10 (5), 1119 (2016). $\underline{\text { Crossref }}$

4. I. V. Stepanova, S.V. Panin, V.G. Durakov, M. A. Korchagin. Russian journal of non-ferrous metals. 54 (1), 112 (2013). Crossref

5. Yu.S. Eliseev, V.V. Krymov, S.A. Kolesnikov, Yu. N. Vasilyev. Nemetalicheskiye kompozitsionnyye materialy $\mathrm{v}$ elementakh konstruktsiy i proizvodstve aviatsionnykh gazoturbinnykh dvigateley. Moscow, MGTU-Salyut (2007) 365 p. (in Russian). [Ю.С. Елисеев, В.В. Крымов, С.А. Колесников, Ю.Н. Васильев. Неметалические композиционные материалы в элементах конструкций и производстве авиационных газотурбинных двигателей. Москва, МГТУ-Салют (2007) 365 с.]

6. X. Huibin, G. Hongbo. Thermal Barrier Coatings. Cambridge, Woodhead Publishing Limited (2011) 360p.

7. S. Bose. High Temperature Coatings. Elsevier Inc (2007) 312 p. Crossref

8. V.I. Bogdanovich, S.B. Maryin, I.A. Dokukina, M.G. Giorbelidze. Tsvetnye Metally. 5, 56 (2016). (in Russian) [В.И. Богданович, С.Б. Марьин, И. А. Докукина, М. Г. Гиорбелидзе. Цветные металлы. 5, 56 (2016).] Crossref

9. V.I. Bogdanovich, M.G. Giorbelidze. IOP Conference Series: Materials Science and Engineering. 177, 1 (2017). Crossref

10. V.I. Bogdanovich, M.G. Giorbelidze. IOP Conference Series: Materials Science and Engineering. 327, 1 (2018). $\underline{\text { Crossref }}$

11. V.I. Bogdanovich, M.G. Giorbelidze. Key Engineering Materials. 685, 685 (2016). Crossref

12. V.I. Bogdanovich, M.G. Giorbelidze. IOP Conference Series: Materials Science and Engineering, 156, 1 (2016). $\underline{\text { Crossref }}$

13. V.I. Bogdanovich, M.G. Giorbelidze. IOP Conference Series: Materials Science and Engineering. 286, 1 (2018). Crossref

14. G.-H. Meng, B.-Y. Zhang, H. Liu, G.-J. Yang, T. Xu, C.-X. Li, C.-J. Li. Surface and Coatings Technology. 347, 54 (2018). $\underline{\text { Crossref }}$ 
15. D. B. Zaytsev, I.A. Treninkov, A.A. Alexeyev. Aviation materials and technologies. 1 (34), 49 (2015). (in Russian) [Д. В. Зайцев, И.А. Тренинков, А.А. Алексеев. Авиационные материалы и технологии. 1 (34), 49 (2015).] Crossref

16. G. V. Bobrov, A.A. Ilin, V.S. Spektor. Theory and technology of inorganic coatings formation. Moscow, Alfa-M (2014) 925 p. (in Russian). [Г.В. Бобров, А.А. Ильин, В.С. Спектор. Теория и технология формирования неорганических покрытий. Москва, Альфа-М (2014) 925 с.]

17. J. J. Skrzypek, A. W. Ganczarski, F. Rustichelli, H. Egner. Advanced Materials and Structures for Extreme Operating Conditions. Berlin, Springer (2008) 258 p.

18. C. Guo, W. Wang, Y. Cheng, S. Zhu and F. Wang. Corrosion Science. 94, 122 (2015). Crossref

19. X. S. M. Jiang, Z. B. Peng, S.C. Bao, Q. M. Liu, J. Wang, C. S. Gong. Corrosion Science. 50, 3213 (2008). Crossref

20. F. Forghan, O. Askari, U. Narusawa, H. Metghalchi.
Journal of energy resources technology. 139 (4), 042004 (2007). Crossref

21. B. P. Kuznetsov, V. P. Lesnikov, I. P. Konakova, N. A. Popov. Metallovedeniye i termicheskaya obrabotka metallov. 9 (711), 40 (2014). (in Russian) [В.П. Кузнецов, В.П. Лесников, И.П. Конакова, Н.А. Попов. Металловедение и термическая обработка металлов. 9 (711), 40 (2014).]

22. F. D. Kiselev. Zavodskaya laboratoriya, Diagnostika materialov. 84 (3), 36 (2018). (in Russian) [Ф. Д Киселев, Заводская лаборатория, Диагностика материалов. 84, (3), 36 (2018).] Crossref

23. L. Yang, M. Chen, J. Wang, S. Zhu, F. Wang. Corrosion Science. 102, 72 (2016). Crossref

24. C. Roger. The superalloy fundamentals and applications. New York, Cambridge University Press (2006) 372p.

25. E. N. Kablov, S. A. Muvoyadzhyan. Metally. 1, 5 (2012). (in Russian) [Е.Н. Каблов, С. А. Мубояджян. Металлы. 1, 5 (2012).] 